\title{
Draft genome sequences and description of Lactobacillus rhamnosus strains L31, L34, and L35
}

\author{
Prapaporn Boonma ${ }^{1,+}$, Jennifer K. Spinler ${ }^{2,3,+,}$, Xiang Qin ${ }^{5}$, Chutima Jittaprasatsin ${ }^{1}$, Donna \\ M. Muzny ${ }^{5}$, Harsha Doddapaneni ${ }^{5}$, Richard Gibbs ${ }^{5}$, Joe Petrosino ${ }^{4,5}$, Somying Tumwasorn ${ }^{6}$, \\ James Versalovic ${ }^{2,3,4}$ \\ ${ }^{1}$ Interdisciplinary Program of Medical Microbiology, Graduate School, Chulalongkorn Uni- \\ versity, Bangkok, Thailand \\ ${ }^{2}$ Texas Children's Microbiome Center, Department of Pathology, Texas Children's Hospital, \\ Houston, Texas, USA \\ ${ }^{3}$ Department of Pathology \& Immunology, Baylor College of Medicine, Houston, Texas, \\ USA \\ ${ }^{4}$ Department of Molecular Virology and Microbiology, Baylor College of Medicine, Hou- \\ ston, Texas, USA \\ ${ }^{5}$ Human Genome Sequencing Center, Baylor College of Medicine, Houston, Texas, USA \\ ${ }^{6}$ Department of Microbiology, Faculty of Medicine, Chulalongkorn University, Bangkok, \\ Thailand \\ †Equal authorship contribution \\ * Correspondence: Jennifer K. Spinler (spinler@bcm.edu)
}

Keywords: Lactobacillus rhamnosus, comparative genomics, probiotics, lactic acid bacteria, anti-inflammatory

Lactobacillus rhamnosus is a facultative, lactic acid bacterium in the phylum Firmicutes. Lactobacillus spp. are generally considered beneficial, and specific strains of L. rhamnosus are validated probiotics. We describe the draft genomes of three L. rhamnosus strains (L31, L34, and L35) isolated from the feces of Thai breastfed infants, which exhibit anti-inflammatory properties in vitro. The three genomes range between $2.8-2.9 \mathrm{Mb}$, and contain approximately 2,700 protein coding genes.

Abbreviations: BCM-HGSC- Baylor College of Medicine Human Genome Sequencing Center, MRSdeMan, Rogosa, Sharpe

\section{Introduction}

Lactobacillus is the largest of three genera within the family Lactobacillaceae, and belongs to one of the dominant phyla, Firmicutes, in the human microbiome [1]. Lactobacillus spp. are naturally isolated from fermented foods [2], and are key members of the human microbiota, reviewed in [3]. In humans, they colonize the oral cavity, gastrointestinal and urogenital tracts, and breast milk [4]. As a whole, this genus is beneficial to humans, possesses many probiotic traits, and is rarely associated with disease.

The human-intestinal isolate, L. rhamnosus strain $\mathrm{GG}$, is one of the most studied and applied probiot- ics. Research has shown that L. rhamnosus GG can modulate host immunity in vitro by decreasing inflammatory cytokine production from various eukaryotic cell lines [5,6], induces intestinal mucin gene expression subsequently inhibiting pathogen adherence in vitro [7]; and attenuates in vitro barrier dysfunction induced by inflammatory cytokines [8]. Here we present the draft genomes and classification summary of three potential probiotic L. rhamnosus strains L31, L34, and L35 isolated from the feces of Thai breastfed infants [9]. Genome sequencing and comparisons of L31, L34, and L35 with the species type-strain, L. rhamnosus GG should help researchers identify distinguishing genetic features important for specific probiotic traits. 


\section{Classification and features}

Within the phylum Firmicutes, the family Lactobacillaceae contains three genera: Lactobacillus, Paralactobacillus, and Pediococcus; Lactobacillus being the largest with latest estimates ranging between 227-230 species (http://www.dsmz.de/bacterialdiversity/prokaryotic-nomenclature-up-todate/prokariotic-nomenclature-up-to-date.html) [10]. Members of Lactobacillus are gram-positive, non-motile, anaerobic, lactic-acid-producing bacilli that are divided into three fermentation groups: A) obligately homofermentative, B) facultatively heterofermentative, and C) obligately heterofermentative [4]. L. rhamnosus resides in fermentation group B and is distinct from the three major Lactobacillus phylogenetic groups based on 16S rRNA gene sequence (L. delbrueckii, $L$. reuteri, and L. salivarius groups) [4]. $L$. rhamnosus strains L31, L34, and L35 are phylogenetically similar to L. rhamnosus GG and maintain a distinctive 16S rRNA gene-based phyologeny from the three major Lactobacillus groups (Figure 1). The basic characteristics of $L$. rhamnosus L31, L34, and L35 are summarized in Table 1.

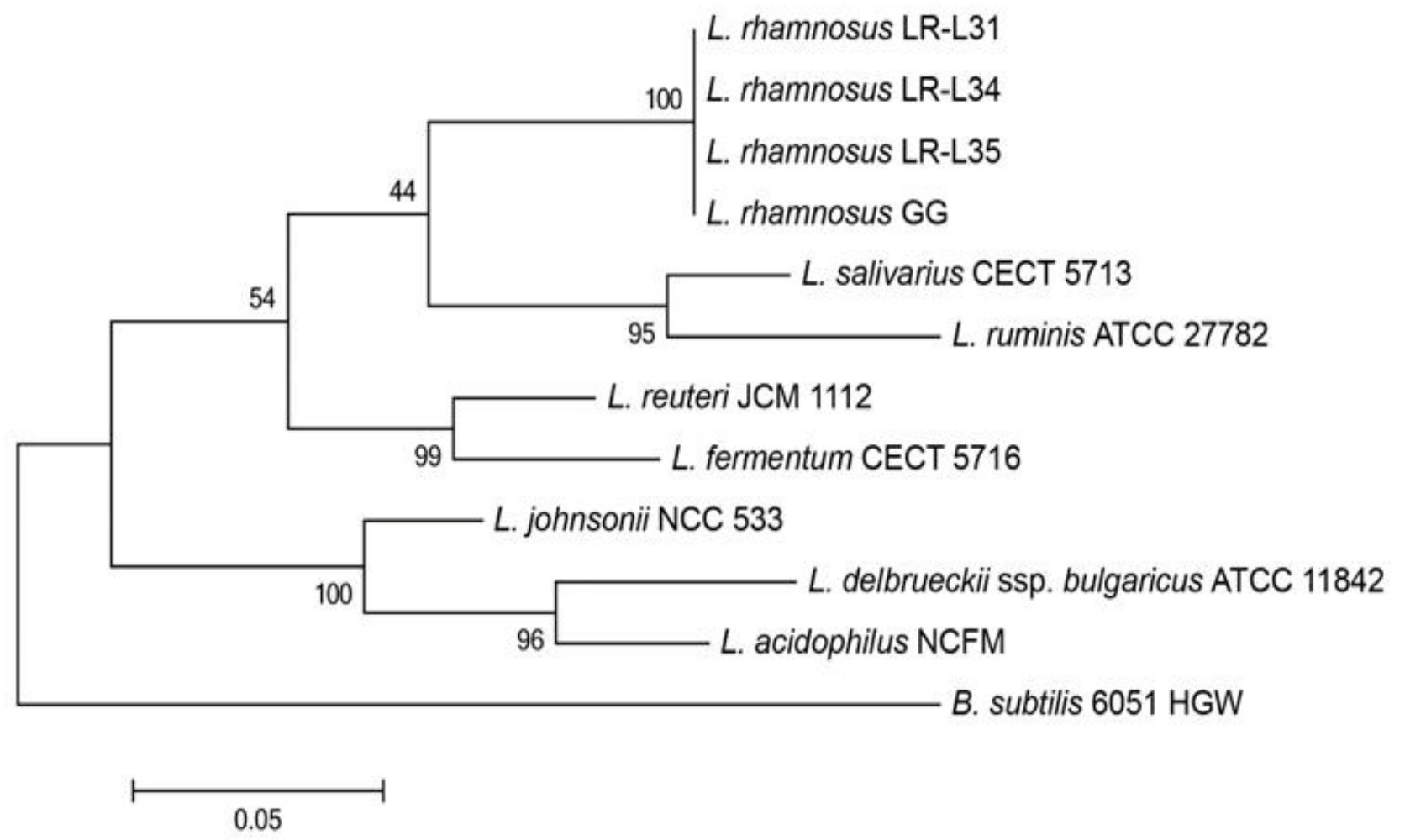

Figure 1. The phylogenetic tree represents the relationships of L. rhamnosus strains L31, L34, and L35 with respect to several members of the genus Lactobacillus. The strains and their corresponding GenBank accession numbers for $16 \mathrm{~S}$ rRNA genes are: L. rhamnsosus strain GG, NC_013198, L. salivarius strain CECT 5713, NC_017481, L. ruminis strain ATCC 27782, NC_015975, L. reuteri strain JCM 1112, NC_010609, L. fermentum strain CECT 5716, NC_017465, L. johnsonii strain NCC 533, NC_005362, L. delbrueckii subsp. bulgaricus strain ATCC 11842, NC_008054, L. acidophilus strain NCFM, NC_006814. Full-length 16S rRNA gene sequences were aligned using ClustalW, and phylogenetic inferences were obtained using the maximum-likelihood method within the MEGA 5.2 software [11] with 1,000 bootstraps. B. subtilis strain 6051 HGW (NC_020507) was used as an outgroup. 
Table 1. Classification and general features of L. rhamnosus strains L31, L34, and L35 according to the MIGS recommendation.

\begin{tabular}{|c|c|c|c|}
\hline MIGS ID & Property & Term & Evidence code $^{\mathrm{a}}$ \\
\hline & \multirow{8}{*}{ Classification } & Domain Bacteria & TAS [12] \\
\hline & & Phylum Firmicutes & TAS [13-15] \\
\hline & & Class Bacillus & TAS [16-18] \\
\hline & & Order Lactobacillales & TAS $[19,20]$ \\
\hline & & Family Lactobacillaceae & TAS $[16,21]$ \\
\hline & & Genus Lactobacillus & TAS $[16,22-26]$ \\
\hline & & Species Lactobacillus rhamnosus & TAS [27] \\
\hline & & Strains L31, L34, and L35 & IDA \\
\hline & Gram stain & Positive & IDA \\
\hline & Cell shape & Rod-shaped & IDA \\
\hline & Motility & Non-motile & NAS \\
\hline & Sporulation & Non-sporulating & NAS \\
\hline & Temperature range & Mesophile & NAS \\
\hline & Optimum temperature & $37^{\circ} \mathrm{C}$ & IDA \\
\hline & Carbon source & Glucose & NAS \\
\hline & Energy source & Lactose, glucose and other sugars & NAS \\
\hline MIGS-6 & Habitat & Human GI Tract & NAS \\
\hline MIGS-22 & Oxygen & Facultative anaerobes & IDA \\
\hline \multirow[t]{3}{*}{ MIGS-15 } & Biotic relationship & Symbiotic relationship & NAS \\
\hline & Pathogenicity & Nonpathogenic; potential probiotic & IDA \\
\hline & Biosafety level & 1 & NAS \\
\hline MIGS-14 & Isolation & Infant feces & IDA \\
\hline MIGS-4 & Geographic location & Bangkok, Thailand & IDA \\
\hline MIGS-5 & Sample collection time & Not reported & \\
\hline MIGS-4.1 & Latitude & $13^{\circ} 45^{\prime} \mathrm{N}$ & IDA \\
\hline MIGS-4.2 & Longitude & $100^{\circ} 35^{\prime} \mathrm{E}$ & IDA \\
\hline MIGS-4.4 & Altitude & Not reported & NAS \\
\hline
\end{tabular}

${ }^{a}$ Evidence codes - IDA: Inferred from Direct Assay; TAS: Traceable Author Statement (i.e., a direct report exists in the literature); NAS: Non-traceable Author Statement (i.e., not directly observed for the living, isolated sample, but based on a generally accepted property for the species, or anecdotal evidence). These evidence codes are from the Gene Ontology project [28].

The colony and Gram stain morphology of $L$. rhamnosus strains L31, L34, and L35 are each depicted in Figure 2. Supernatants from $L$. rhamnosus L34 and L35, both isolated from the same 40 day old female, suppress LPS-induced TNF- $\alpha$ production by THP-1 cells [9] and $C$. difficile-induced IL-8 production by HT-29 cells [29]. Similarly, strain L31, isolated from a 39 day old female, suppresses LPS-induced TNF- $\alpha$ production by THP-1 cells, however does not suppress $C$. difficile-induced IL-8 production by HT-29 cells [29]. All three strains are resistant to two drugs commonly used to treat $C$. difficile infection in humans, vancomycin and metronidazole (MIC90 $>256 \mu \mathrm{g} / \mathrm{mL}$ for each), but are susceptible to low concentrations (MIC90 $=2 \mu \mathrm{g} / \mathrm{mL}$ ) of the newest antibiotic targeting $C$. difficile, fidaxomicin. These strain-specific characteristics suggest $L$. rhamnosus L34 and L35 are potential probiotic candidates for either preventing or treating $C$. difficile disease. 


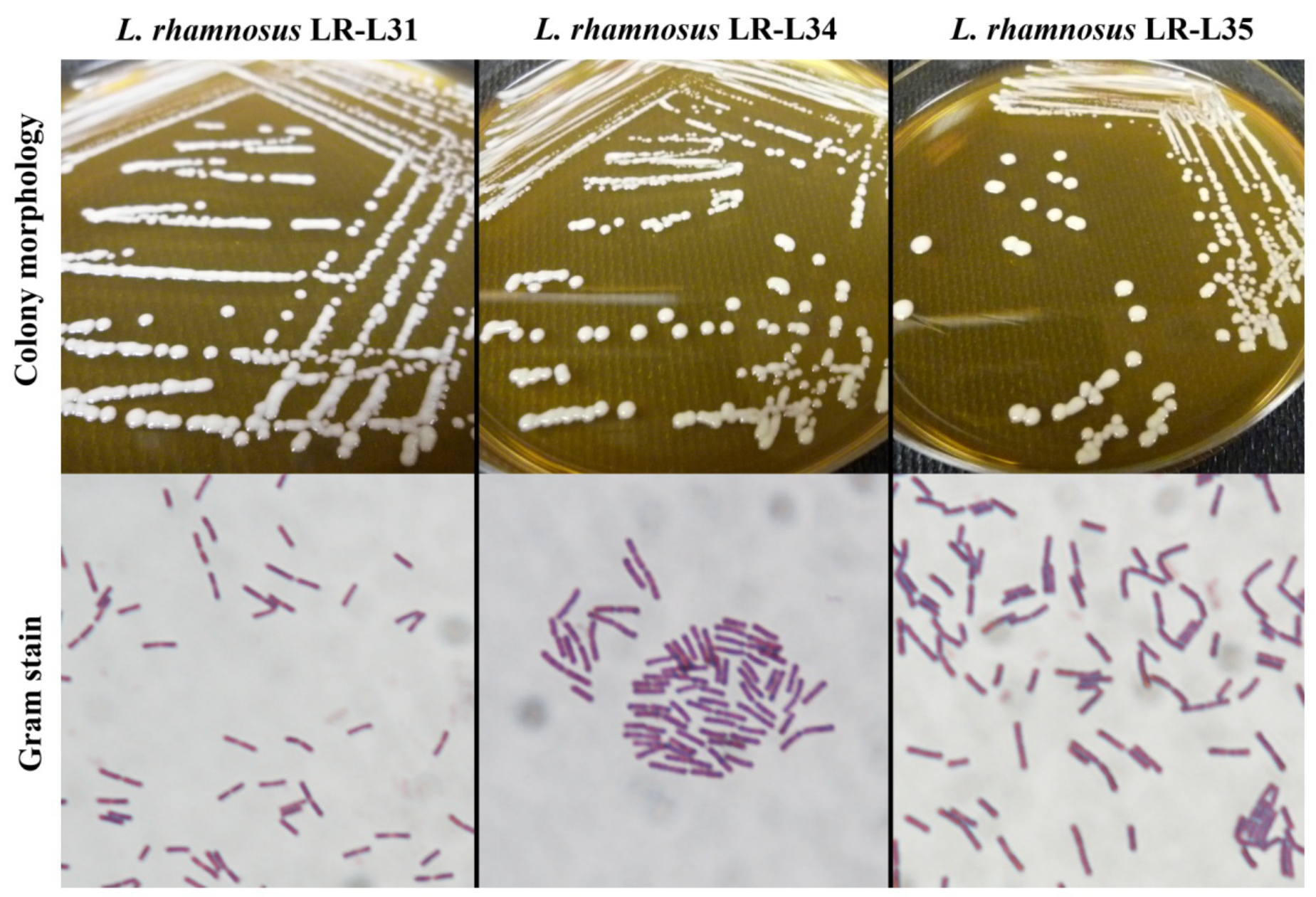

Figure 2. Colony morphology and Gram stains of L. rhamnosus strains L31, L34, and L35. L. rhamnosus strains were cultured anaerobically on MRS agar at $37^{\circ} \mathrm{C}$ for $48 \mathrm{hr}$. Gram stains were carried out using standard methods, and images were taken under oil emersion at $100 \times$ magnification.

\section{Genome sequencing information}

\section{Genome project history}

L. rhamnosus strains L31, L34, and L35 were selected for sequencing based on the properties described above. The draft genome sequence for each strain was finished in October 2012. The Whole Genome Shotgun projects for L. rhamnosus L31, L34, and L35 have been deposited at DDBJ/EMBL/GenBank under the accession numbers AYTQ00000000, AYTR00000000, and AYTP0000000, respectively. The versions de- scribed in this paper are AYTQ01000000, AYTR01000000, and AYTP0100000, respectively. The genome projects for L31, L34, and L35 are listed in the Genome OnLine Database (GOLD) [30] as projects Gi0036900, Gi0036903, and Gi0036905, respectively. Genome sequencing and assembly was completed at Baylor College of Medicine's Human Genome Sequencing Center (BCMHGSC). Automatic annotation was performed using the DOE-JGI Microbial Annotation Pipeline (DOE-JGI MAP). Table 2 shows the project information and its association with MIGS version 2.0 compliance [31], 
.Table 2. Project information

\begin{tabular}{lllll}
\hline & & L31 & L34 & L35 \\
\hline MIGS ID & Property & Term & Term & Term \\
\hline MIGS-31 & Finishing quality & Standard Draft & Standard Draft & Standard Draft \\
MIGS-28 & Libraries used & 8 kb, mate paired library & 8 kb, mate paired library & 8 kb, mate paired library \\
MIGS-29 & Sequencing platforms & 454 GS FLX & 454 GS FLX & 454 GS FLX \\
MIGS- & & & \\
31.2 & Fold coverage & $23 \times$ & $29 \times$ & $26 \times$ \\
MIGS-30 & Assemblers & Newbler v2.5.3 & Newbler v2.5.3 & Newbler v2.5.3 \\
MIGS-32 & Gene calling method & Prodigal & Prodigal & Prodigal \\
& Genome Database release & March 1, 2014 & March 1, 2014 & March 1, 2014 \\
& GenBank ID & AYTQ00000000 & AYTR00000000 & AYTP00000000 \\
& GenBank Date of Release & March 1, 2014 & March 1, 2014 & March 1, 2014 \\
& GOLD ID & Gi0036900 & Gi0036903 & Gi0036905 \\
& Project relevance & Potential probiotic & Potential probiotic & Potential probiotic \\
\hline
\end{tabular}

\section{Growth conditions and DNA isolation}

L. rhamnosus strains L31, L34, and L35 were routinely cultured in an anaerobic chamber (Concept Plus, Ruskinn Technology, UK) $\left(10 \% \mathrm{CO}_{2}, 10 \% \mathrm{H}_{2}\right.$, and $80 \% \mathrm{~N}_{2}$ ) for $24-48 \mathrm{~h}$ at $37^{\circ} \mathrm{C}$ in de Man, Rogosa, Sharpe (MRS) medium (Oxoid, England). For genomic DNA isolation, cultures were adjusted to an $\mathrm{OD}_{600}$ of 0.1 and incubated anaerobically at $37^{\circ} \mathrm{C}$ for $8 \mathrm{~h}$. Bacterial pellets were collected by centrifugation and the DNA was extracted using QIAGEN Genomic-tip100/G columns (Qiagen, Germany) according to the manufacturer's instructions. DNA quality was analyzed by agarose gel electrophoresis, and concentrations were determined by fluorescence using the Qubit ${ }^{\mathrm{TM}}$ DNA Assay (Life Technologies, USA).

\section{Genome sequencing and assembly}

The genomes of L. rhamnosus strains L31, L34, and L35 were sequenced at the BCM-HGSC, USA on a Roche 454 GS FLX sequencing platform. A fragment sequencing approach was implemented using $8 \mathrm{~kb}$ libraries generated by long insert mate paired construction, as detailed in the Human Microbiome Project Reference Genome Project protocol [32] to about $23 \times(254,342$ reads), $29 \times$ (283,036 reads), and $26 \times$ (249,176 reads) sequence depth coverage, respectively, with an estimated read alignment error rate of $0.84 \%$. The sequence data were assembled using the Newbler assembler version 2.5.3. The final assemblies resulted in 67 (L31), 51 (L34), and 51 (L35) contigs generating corresponding genome sizes of 2.8, 2.9, and $2.9 \mathrm{Mb}$ in 3, 3, and 4 scaffolds.

\section{Genome annotation}

Open Reading Frames (ORFs) were predicted using Prodigal $[33,34]$ as part of the Oak Ridge National Laboratory genome annotation pipeline, followed by a round of manual curation using the JGI GenePRIMP pipeline [35]. The predicted protein coding sequences (CDSs) were translated and searched against the National Center for Biotechnology Information (NCBI) non-redundant database, UniProt, TIGRFam, Pfam, PRIAM, KEGG, COG, and InterPro databases [35]. These data sources were combined to assert a product description for each predicted protein. Additional gene prediction analysis and manual functional annotation was performed with the Integrated Microbial Genomes Expert Review (IMG-ER) platform [36]. Noncoding genes and miscellaneous features were predicted using tRNAscan-SE [37], RNAMMer [38], Rfam [39], TMHMM [40], and signalP [41].

\section{Genome properties}

The properties and statistics for the three $L$. rhamnosus genomes are summarized in Table 3 . The distribution of genes into COG functional categories for each genome is detailed in Table 4. The L. rhamnosus L31 genome was assembled into 67 contigs (ranging from 551 - 290,053 bp) forming one presumptive circular chromosome of $2,826,754$ base pairs ( $46.73 \%$ GC content). A total of 2,749 ORFs were predicted: 2,687 are proteincoding genes, and 62 are RNA genes. A total of $2,173(79.05 \%)$ protein-coding genes were assigned a putative function. The L34 genome was assembled into 51 contigs (ranging from 288 $237,520 \mathrm{bp}$ ) forming a presumptive single circular 
chromosome of $2,937,717$ base pairs $(46.81 \%$ GC content). A total of 2,845 ORFs were predicted: 2,774 are protein-coding genes, and 71 are RNA genes. A total of 2,216 (77.89\%) protein coding genes were assigned a putative function. Finally, the L35 genome was assembled into 51 contigs (687 - 226,797 bp) forming one presumptive chromosome of 2,937,403 base pairs (46.81\%). A total of 2,842 ORFs were predicted: 2,772 are protein-coding genes, and 70 are RNA genes. A total of $2,217(78.01 \%)$ protein coding genes were assigned a putative function.

\section{Comparison with Lactobacillus rhamnosus strain GG}

The beneficial effects of human-intestinal derived L. rhamnosus GG have been studied for two decades [42-45] and its complete genome is available in NCBI [46]. We have compared the draft genome sequences of the potential probiotic L. rhamnosus strains L31, L34, and L35 to L. rhamnosus GG. The L. rhamnosus GG genome $(3,010,111 \mathrm{bp}, 46.69 \%$ GC content) is slightly larger than the new genomes presented here, and has approximately the same GC content (Table 3). In a recent compara- tive genomics study of 100 L. rhamnosus strains, Douillard, et al. [47] delineated seventeen variable chromosomal regions of L. rhamnosus strain GG (annotated in Figure 3), and the majority of these regions are absent or incomplete in the genomes of strains L31, L34, and L35 (Figure 3), notably the spaCBA pili gene cluster required for mucus adhesion [46]. The galactitol PTS region important for dulcitol utilization, a trait that typically belongs to L. rhamnosus isolates adapted to the intestinal tract [47], is conserved in L31, L34, and L35. Similar to L. rhamnosus GG, L31, L34, and L35 each contain genes annotated as L-lactate dehydrogenase (IdhL) and D-lactate dehydrogenase (ldhD) important for synthesizing L-lactate and D-lactate from pyruvate, respectively [49]. L. rhamnosus GG is unable to metabolize either maltose due to an inserted gene between the maltose-specific transport genes and hydrolase, or lactose because of a $38 \mathrm{bp} \mathrm{N}$-terminal truncation in lacT and a disrupted lacG $[47,50]$. Strains L31, L34, and L35 all have an intact maltose locus and carry nonmutated copies of lacT and lacG (locations indicated on Figure 3), and therefore are predicted to utilize both maltose and lactose.

Table 3. Nucleotide content and gene count levels of the genome

\begin{tabular}{|c|c|c|c|c|c|c|}
\hline & L31 & & L34 & & $\mathbf{L 3 5}$ & \\
\hline Attribute & Value & $\begin{array}{l}\% \text { of } \\
\text { total }^{\text {a }}\end{array}$ & Value & $\begin{array}{l}\% \text { of } \\
\text { total }^{\mathrm{a}}\end{array}$ & Value & $\begin{array}{l}\% \text { of } \\
\text { total }^{\mathrm{a}}\end{array}$ \\
\hline Genome Size (bp) & $2,826,754$ & 100 & $2,937,717$ & 100 & $2,937,403$ & 100 \\
\hline DNA G+C content $(b p)$ & $1,320,949$ & 46.73 & $1,375,266$ & 46.81 & $1,375,134$ & 46.81 \\
\hline DNA coding region (bp) & $2,422,731$ & 85.71 & $2,519,202$ & 85.75 & $2,517,453$ & 85.70 \\
\hline Total genes & 2,749 & 100 & 2,854 & 100 & 2,842 & 100 \\
\hline RNA genes & 62 & 2.26 & 71 & 2.50 & 70 & 2.46 \\
\hline Protein-coding genes & 2,687 & 97.74 & 2,774 & 97.50 & 2,772 & 97.54 \\
\hline Genes with functional prediction & 2,173 & 79.05 & 2,216 & 77.89 & 2,217 & 78.01 \\
\hline Genes in paralog clusters & 1,818 & 66.13 & 1,898 & 66.71 & 1,869 & 65.76 \\
\hline Genes assigned to COGs & 2,121 & 77.16 & 2,150 & 75.57 & 2,151 & 75.69 \\
\hline Genes assigned to KOGs & 886 & 32.23 & 913 & 32.09 & 914 & 32.16 \\
\hline Genes assigned to Pfam & 2,209 & 80.36 & 2,250 & 79.09 & 2,254 & 79.31 \\
\hline Genes assigned to TIGRfam & 880 & 31.01 & 893 & 31.39 & 892 & 31.39 \\
\hline Genes with signal peptides & 138 & 5.02 & 139 & 4.89 & 138 & 4.86 \\
\hline Genes with transmembrane helices & 813 & 29.57 & 835 & 29.35 & 834 & 29.35 \\
\hline
\end{tabular}

${ }^{a}$ The total is based on either the size of the genome in base pairs or the total number of protein coding genes in the annotated genome 
Table 4. Number of genes associated with the 25 general COG functional categories

\begin{tabular}{|c|c|c|c|c|c|c|c|}
\hline & L31 & & L34 & & L35 & & \\
\hline Code & Value & $\%$ age $^{a}$ & Value & $\%$ age $^{a}$ & Value & $\%$ age $^{a}$ & Description \\
\hline$J$ & 150 & 6.56 & 150 & 6.49 & 150 & 6.48 & Translation \\
\hline A & - & - & - & - & - & - & RNA processing and modification \\
\hline K & 203 & 8.88 & 206 & 8.91 & 207 & 8.95 & Transcription \\
\hline $\mathrm{L}$ & 123 & 5.38 & 132 & 5.71 & 134 & 5.79 & $\begin{array}{l}\text { Replication, recombination and re- } \\
\text { pair }\end{array}$ \\
\hline B & - & - & - & - & - & - & Chromatin structure and dynamics \\
\hline $\mathrm{D}$ & 33 & 1.44 & 29 & 1.25 & 29 & 1.25 & $\begin{array}{l}\text { Cell cycle control, mitosis and mei- } \\
\text { osis }\end{array}$ \\
\hline Y & - & - & - & - & - & - & Nuclear structure \\
\hline V & 75 & 3.28 & 79 & 3.42 & 79 & 3.41 & Defense mechanisms \\
\hline $\mathrm{T}$ & 82 & 3.59 & 84 & 3.63 & 85 & 3.67 & Signal transduction mechanisms \\
\hline M & 129 & 5.65 & 128 & 5.54 & 127 & 5.49 & Cell wall/membrane biogenesis \\
\hline $\mathrm{N}$ & 9 & 0.39 & 8 & 0.35 & 8 & 0.35 & Cell motility \\
\hline Z & - & - & - & - & - & - & Cytoskeleton \\
\hline W & - & - & - & - & - & - & Extracellular structures \\
\hline$U$ & 28 & 1.23 & 23 & 0.99 & 23 & 0.99 & $\begin{array}{l}\text { Intracellular trafficking and secre- } \\
\text { tion }\end{array}$ \\
\hline $\mathrm{O}$ & 59 & 2.58 & 59 & 2.55 & 59 & 2.5 & $\begin{array}{l}\text { Posttranslational modification, pro- } \\
\text { tein turnover, chaperones }\end{array}$ \\
\hline $\mathrm{C}$ & 90 & 3.94 & 87 & 3.76 & 88 & 3.80 & Energy production and conversion \\
\hline G & 303 & 13.26 & 315 & 13.62 & 315 & 13.61 & $\begin{array}{l}\text { Carbohydrate transport and metabo- } \\
\text { lism }\end{array}$ \\
\hline E & 183 & 8.01 & 178 & 7.70 & 177 & 7.65 & $\begin{array}{l}\text { Amino acid transport and metabo- } \\
\text { lism }\end{array}$ \\
\hline $\mathrm{F}$ & 87 & 3.81 & 85 & 3.68 & 85 & 3.67 & $\begin{array}{l}\text { Nucleotide transport and metabo- } \\
\text { lism }\end{array}$ \\
\hline $\mathrm{H}$ & 58 & 2.54 & 60 & 2.60 & 60 & 2.59 & $\begin{array}{l}\text { Coenzyme transport and metabo- } \\
\text { lism }\end{array}$ \\
\hline I & 55 & 2.41 & 57 & 2.47 & 57 & 2.46 & Lipid transport and metabolism \\
\hline$P$ & 96 & 4.20 & 95 & 4.11 & 95 & 4.11 & $\begin{array}{l}\text { Inorganic ion transport and metabo- } \\
\text { lism }\end{array}$ \\
\hline Q & 21 & 0.92 & 21 & 0.91 & 21 & 0.91 & $\begin{array}{l}\text { Secondary metabolites biosynthesis, } \\
\text { transport and catabolism }\end{array}$ \\
\hline $\mathrm{R}$ & 285 & 12.47 & 292 & 12.63 & 291 & 12.58 & General function prediction only \\
\hline S & 216 & 9.45 & 224 & 9.69 & 224 & 9.68 & Function unknown \\
\hline- & 628 & 22.84 & 695 & 24.43 & 691 & 24.31 & Not in COGs \\
\hline
\end{tabular}

${ }^{a}$ The total is based on the total number of protein coding genes in the annotated genome. 




Figure 3. Circular representation of $3 \mathrm{draft} L$. rhamnosus genomes compared against L. rhamnosus strain GG (NC_ 013198). The innermost rings show GC content (black) and GC skew (purple/green). The remaining rings show BLASTn results of each genome against L. rhamnosus GG with results rendered using the BRIG program [48]. Relative shading density (from darker to lighter) within each circle represents levels of nucleotide homology. Blank regions represent absent genetic regions. Genetic regions of interest are annotated on the outermost ring. Numbered elements (1-17) represent the previously identified variable chromosomal regions of L. rhamnosus GG [47].

In line with the anti-inflammatory phenotypic differences already noted [9,29], differences in genomic features between L. rhamnosus L31 and the two isolates, L34 and L35, can also be made relative to strain GG. The taurine transport system deemed important for bile resistance as well as the fucU, fucI, $f c s R$, and $\alpha$-L-fucosidase genes required for metabolizing fucosylated compounds present in gastrointestinal environments are found in L34 and L35 genomes, but not in L31. $L$. rhamnosus GG, despite belonging to a species known for rhamnose utilization, possesses an altered rhamnose locus and cannot utilize rhamnose [46]. L. rhamnosus L31 contains an intact rhamnose locus, while this locus in strains L34 and L35 looks similarly disrupted to that of strain GG. It is also noteworthy that L. rhamnosus L31 contains an iron-transport and a general secretion system not present in strains L34, L35, or GG.

\section{Conclusion}

Here we have presented the draft genomes of three potential probiotic strains of L. rhamnosus: L31, L34, and L35. Brief genome comparisons indicate that strains L34 and L35 are most similar to L. rhamnosus GG, while L31 contains marked differences suggesting it may have originated from a slightly different ecological niche [47]. L. rhamnosus L34 and L35 were isolated from the same host based on initial distinguishing colony morphology [9], however current colony morphology for these strains is not unique (Figure 2) and comparison of the draft genomes suggests the two genomes are nearly identical and similarly distinct from L31. It is possible that L34 and L35 may represent isolates of the same strain. Future studies will combine functional data with genomics, which is a powerful method for not only validating probiotic features of beneficial mi- 
crobes, but also for learning about the environmental adaptations that have favored their mutual relationship with human hosts.

\section{Acknowledgments}

The authors would like to acknowledge the Texas Children's Microbiome Center for providing equipment and resources for a fruitful collaboration. This work was supported by the $\mathrm{NIH} /$ National Institute of Diabetes and Digestive and Kidney Disease Grants P30 DK56338 (JV) and 5UH3DK083990-04 (JV), as well as the Thailand Research Fund through the Royal Golden Jubilee PhD Program (PHD/0295/2550) (PB), and the Rachadapisek Sompoj Research Fund, Faculty Medicine, Chulalongkorn University (Grant No. RA51/1 and RA55/20) (ST).

\section{References}

1. Human Microbiome Project Consortium. Structure, function and diversity of the healthy human microbiome. Nature 2012; 486:207-214. PubMed http://dx.doi.org/10.1038/nature11234

2. Bernardeau M, Vernoux JP, Henri-Dubernet $S$, Guéguen M. Safety assessment of dairy microorganisms: the Lactobacillus genus. Int I Food Microbiol 2008; 126:278-285. PubMed http://dx.doi.org/10.1016/j.ijfoodmicro.2007.08.0 $\underline{15}$

3. Spinler JK. Human Microbiome, Lactobacillaceae in the. In: Nelson K, editor. Encyclopedia of Metagenomics. Verlag Berlin Heidelberg: Springer; 2013.

4. Schleifer KH. Family I. Lactobacillaceae Winslow, Broadhurst, Buchanan, Krumwiede, Rogers and Smith 1917, familia. In: De Vos PG, G.M.; Jones, D.; Krieg, N.R.; Ludwig, W.; Rainey, F.A.; Schleifer, K.H.; Whitman, W.B., editor. Bergey's Manual of Systematic Bacteriology, Volume Three The Firmicutes. 2nd ed. Volume 3, TheFirmicutes. New York: Springer; 2009. p 465-532.

5. Peña JA, Versalovic J. Lactobacillus rhamnosus GG decreases TNF-alpha production in lipopolysaccharide-activated murine macrophages by a contact-independent mechanism. Cell Microbiol 2003; 5:277-285. PubMed http://dx.doi.org/10.1046/j.1462-5822.2003.t011-00275.x

6. Zhang L, Li N, Caicedo R, Neu J. Alive and dead Lactobacillus rhamnosus GG decrease tumor necrosis factor-alpha-induced interleukin-8 production in Caco-2 cells. J Nutr 2005; 135:1752-1756. PubMed

7. Mack DR, Michail S, Wei S, McDougall L, Hollingsworth MA. Probiotics inhibit enteropathogenic $E$. coli adherence in vitro by inducing intestinal mucin gene expression. Am J Physiol 1999; 276:G941-G950. PubMed

8. Donato KA, Gareau MG, Wang YJ, Sherman PM. Lactobacillus rhamnosus GG attenuates interferon-\{gamma\} and tumour necrosis factor-alphainduced barrier dysfunction and pro-inflammatory signalling. Microbiology 2010; 156:3288-3297. PubMed http://dx.doi.org/10.1099/mic.0.040139$\underline{0}$

9. Jittaprasatsin C. Quantification and determination of antagonistic activity of bifidobacteria and lactobacilli in faeces of breast-fed and mixed-fed infants. Bangkok, Thailand: Chulalongkorn University; 2008. 113 p.

10. Euzéby JP. List of Bacterial Names with Standing in Nomenclature: a folder available on the Internet. Int J Syst Bacteriol 1997; 47:590-592. PubMed http://dx.doi.org/10.1099/00207713-472-590

11. Tamura K, Peterson D, Peterson N, Stecher G, Nei M, Kumar S. MEGA5: molecular evolutionary genetics analysis using maximum likelihood, evolutionary distance, and maximum parsimony methods. Mol Biol Evol 2011; 28:2731-2739. PubMed http://dx.doi.org/10.1093/molbev/msr121

12. Woese CR, Kandler O, Wheelis ML. Towards a natural system of organisms: proposal for the domains Archaea, Bacteria, and Eucarya. Proc Natl Acad Sci USA 1990; 87:4576-4579. PubMed http://dx.doi.org/10.1073/pnas.87.12.4576

13. Gibbons NE, Murray RGE. Proposals concerning the higher taxa of bacteria. Int / Syst Bacteriol 1978; 28:1-6. http://dx.doi.org/10.1099/00207713-28-1-1

14. Garrity G, Holt J. The Road Map to the Manual. Bergey's Manual of Systematic Bacteriology. Volume 1. New York: Springer; 2001. p 119-169.

15. Murray RGE. The Higher Taxa, or, a Place for Everything...? In: Holt JG (ed), Bergey's Manual of Systematic Bacteriology, First Edition, Volume 1, The Williams and Wilkins Co., Baltimore, 1984, p. 31-34.

16. Skerman VBD, McGowan V, Sneath PHA. Approved Lists of Bacterial Names. Int I Syst Bacteriol 1980; 30:225-420. http://dx.doi.org/10.1099/00207713-30-1-225

17. Cohn F. Untersuchungen über Bakterien. Beitr Biol Pflanz 1872; 1:127-224.

18. Gibson T, Gordon RE. Genus I. Bacillus Cohn 1872, 174; Nom. gen. cons. Nomencl. Comm. Intern. Soc. Microbiol. 1937, 28; Opin. A. Jud. Comm. 1955, 39. In: Buchanan RE, Gibbons NE (eds), Bergey's Manual of Determinative Bac- 
teriology, Eighth Edition, The Williams and Wilkins Co., Baltimore, 1974, p. 529-550.

19. List of new names and new combinations previously effectively, but not validly, published. List no. 132. Int / Syst Evol Microbiol 2010; 60:469472. http://dx.doi.org/10.1099/ijs.0.022855-0

20. Ludwig W, Schleifer KH, Whitman WB. Order II. Lactobacillales ord. nov. In: De Vos P, Garrity G, Jones D, Krieg NR, Ludwig W, Rainey FA, Schleifer KH, Whitman WB (eds), Bergey's Manual of Systematic Bacteriology, Second Edition, Volume 3, Springer-Verlag, New York, 2009, p. 464.

21. Winslow CEA, Broadhurst J, Buchanan RE, Krumwiede C, Rogers LA, Smith GH. The Families and Genera of the Bacteria: Preliminary Report of the Committee of the Society of American Bacteriologists on Characterization and Classification of Bacterial Types. J Bacteriol 1917; 2:505566. PubMed

22. Beijerinck MW. Sur les ferments lactiques de I'industrie. Archives Néerlandaises des Sciences Exactes et Naturelles 1901; 6:212-243.

23. Cai Y, Pang H, Kitahara M, Ohkuma M. Lactobacillus nasuensis sp. nov., a lactic acid bacterium isolated from silage, and emended description of the genus Lactobacillus. Int I Syst Evol Microbiol 2012; 62:1140-1144. PubMed http://dx.doi.org/10.1099/ijs.0.031781-0

24. Rogosa M. Genus Lactobacillus Beijerinck 1901, 212; Nom. cons. Opin. 38, Jud. Comm. 1971, 104. In: Buchanan RE, Gibbons NE (eds), Bergey's Manual of Determinative Bacteriology, Eighth Edition, The Williams and Wilkins Co., Baltimore, 1974, p. 576-593.

25. Haakensen M, Dobson CM, Hill JE, Ziola B. Reclassification of Pediococcus dextrinicus (Coster and White 1964) Back 1978 (Approved Lists 1980) as Lactobacillus dextrinicus comb. nov., and emended description of the genus Lactobacillus. Int I Syst Evol Microbiol 2009; 59:615-621. PubMed http://dx.doi.org/10.1099/ijs.0.65779-0

26. Editorial Secretary (for the Judicial Commission of the International Committee on Systematic Bacteriology). Opinion 38: Conservation of the Generic Name Lactobacillus Beijerinck. Int I Syst Bacteriol 1971; $21: 104$. http://dx.doi.org/10.1099/00207713-21-1-104

27. Felis GE, Dellaglio F. Taxonomy of Lactobacilli and Bifidobacteria. Curr Issues Intest Microbiol 2007; 8:44-61. PubMed

28. Ashburner M, Ball CA, Blake JA, Botstein D, Butler H, Cherry JM, Davis AP, Dolinski K, Dwight SS, Eppig JT, et al. Gene ontology: tool for the unification of biology. The Gene Ontology Con- sortium. Nat Genet 2000; 25:25-29. PubMed

http://dx.doi.org/10.1038/75556

29. Boonma P. Role of Lactobacillus in the suppression of Clostridium difficile-induced IL-8 production in colonic epithelial cells. Bangkok, Thailand: Chulalongkorn University; 2013. 120 p.

30. Liolios K, Chen IM, Mavromatis K, Tavernarakis N, Hugenholtz P, Markowitz VM, Kyrpides NC. The Genomes On Line Database (GOLD) in 2009: status of genomic and metagenomic projects and their associated metadata. Nucleic Acids Res 2010; 38:D346-D354. PubMed http://dx.doi.org/10.1093/nar/gkp848

31. Field D, Garrity G, Gray T, Morrison N, Selengut J, Sterk P, Tatusova T, Thomson N, Allen MJ, Angiuoli SV, et al. The minimum information about a genome sequence (MIGS) specification. Nat Biotechnol 2008; 26:541-547. PubMed http://dx.doi.org/10.1038/nbt1360

32. Nelson KE, Weinstock GM, Highlander SK, Worley KC, Creasy HH, Wortman JR, Rusch DB, Mitreva M, Sodergren E, Chinwalla AT, et al. A catalog of reference genomes from the human microbiome. Science 2010; 328:994-999. $\underline{\text { PubMed }}$ http://dx.doi.org/10.1126/science.1183605

33. Claesson MJ, van Sinderen D, O'Toole PW. Lactobacillus phylogenomics--towards a reclassification of the genus. Int / Syst Evol Microbiol 2008; 58:2945-2954. PubMed http://dx.doi.org/10.1099/ijs.0.65848-0

34. Hyatt D, Chen GL, Locascio PF, Land ML, Larimer FW, Hauser LJ. Prodigal: prokaryotic gene recognition and translation initiation site identification. BMC Bioinformatics 2010; 11:119. PubMed http://dx.doi.org/10.1186/1471-2105-11$\underline{119}$

35. Pati A, Ivanova NN, Mikhailova N, Ovchinnikova G, Hooper SD, Lykidis A, Kyrpides NC.

GenePRIMP: a gene prediction improvement pipeline for prokaryotic genomes. Nat Methods 2010; 7:455-457. PubMed http://dx.doi.org/10.1038/nmeth.1457

36. Markowitz VM, Mavromatis K, Ivanova NN, Chen IM, Chu K, Kyrpides NC. IMG ER: a system for microbial genome annotation expert review and curation. Bioinformatics 2009; 25:2271-2278.

$\underline{\text { PubMed }}$ http://dx.doi.org/10.1093/bioinformatics/btp393

37. Lowe TM, Eddy SR. tRNAscan-SE: a program for improved detection of transfer RNA genes in genomic sequence. Nucleic Acids Res 1997; 25:955-964. PubMed http://dx.doi.org/10.1093/nar/25.5.0955

38. Lagesen K, Hallin P, Rodland EA, Staerfeldt HH, Rognes T, Ussery DW. RNAmmer: consistent and 
rapid annotation of ribosomal RNA genes. Nucleic Acids Res 2007; 35:3100-3108. PubMed http://dx.doi.org/10.1093/nar/gkm160

39. Griffiths-Jones S, Bateman A, Marshall M, Khanna A, Eddy SR. Rfam: an RNA family database. $\mathrm{Nu}$ cleic Acids Res 2003; 31:439-441. PubMed http://dx.doi.org/10.1093/nar/gkg006

40. Krogh A, Larsson B, von Heijne G, Sonnhammer EL. Predicting transmembrane protein topology with a hidden Markov model: application to complete genomes. J Mol Biol 2001; 305:567580. PubMed http://dx.doi.org/10.1006/jmbi.2000.4315

41. Bendtsen JD, Nielsen H, von Heijne G, Brunak S. Improved prediction of signal peptides: SignalP 3.0. J Mol Biol 2004; 340:783-795. PubMed http://dx.doi.org/10.1016/j.jmb.2004.05.028

42. Saxelin M, Pessi T, Salminen S. Fecal recovery following oral administration of Lactobacillus strain GG (ATCC 53103) in gelatine capsules to healthy volunteers. Int J Food Microbiol 1995; 25:199-203. PubMed http://dx.doi.org/10.1016/0168-1605(94)00091-J

43. Guarino A, Lo Vecchio A, Canani RB. Probiotics as prevention and treatment for diarrhea. Curr Opin Gastroenterol 2009; 25:18-23. PubMed http://dx.doi.org/10.1097/MOG.0b013e32831b44 $\underline{55}$

44. Saxelin M, Tynkkynen S, Mattila-Sandholm T, de Vos WM. Probiotic and other functional microbes: from markets to mechanisms. Curr Opin Biotechnol 2005; 16:204-211. PubMed http://dx.doi.org/10.1016/j.copbio.2005.02.003

45. Vanderhoof JA, Mitmesser SH. Probiotics in the management of children with allergy and other disorders of intestinal inflammation. Benef $\mathrm{Mi}$ crobes 2010; 1:351-356. PubMed http://dx.doi.org/10.3920/BM2010.0034

46. Kankainen M, Paulin L, Tynkkynen S, von Ossowski I, Reunanen J, Partanen P, Satokari R, Vesterlund S, Hendrickx AP, Lebeer S, et al. Comparative genomic analysis of Lactobacillus rhamnosus GG reveals pili containing a humanmucus binding protein. Proc Natl Acad Sci USA 2009; 106:17193-17198. PubMed http://dx.doi.org/10.1073/pnas.0908876106

47. Douillard FP, Ribbera A, Kant R, Pietila TE, Jarvinen HM, Messing M, Randazzo CL, Paulin L, Laine P, Ritari J, et al. Comparative Genomic and Functional Analysis of 100 Lactobacillus rhamnosus Strains and Their Comparison with Strain GG. PLoS Genet 2013; 9:e1003683. PubMed http://dx.doi.org/10.1371/journal.pgen.1003683

48. Alikhan NF, Petty NK, Ben Zakour NL, Beatson SA. BLAST Ring Image Generator (BRIG): simple prokaryote genome comparisons. BMC Genomics 2011; 12:402. PubMed http://dx.doi.org/10.1186/1471-2164-12-402

49. Ferain T, Garmyn D, Bernard N, Hols P, Delcour J. Lactobacillus plantarum IdhL gene: overexpression and deletion. J Bacteriol 1994; 176:596-601. PubMed

50. Tsai YK, Lin TH. Sequence, organization, transcription and regulation of lactose and galactose operons in Lactobacillus rhamnosus TCELL-1. J Appl Microbiol 2006; 100:446-459. PubMed http://dx.doi.org/10.1111/j.13652672.2005.02790.x 